\title{
カンキッそばかす病に対するワイダック乳剂の防除効果
}

\author{
山本滋・磯 田隆晴（熊本県果樹試験場）
}

カンキツそばかす病は，エンドウ褐紋病菌によって発 生するが，この防除には，エンドウの褐紋病を防ぐこと と，エンドウ収檴後に，枯死茎葉を処分することが大切 である。しかし，エンドウの枯死茎葉の処分は，学力の 問題もあって央行されず，そのまま畑に放置している場 合が多く、これからのミカンへの感染がかなり多い。一 方，有機物としてエンドウがらを：ミカン園に利用した いなどの意見もあって，薬剤によるエンドウがらの処理 法について検討した結果，ワイダック乳剤処理は，防除 効果があることがわかったのでここに報告する。

\section{I ．薬剤によるエンドウがら処理試験}

実験 1 胎和46年 6 月 7 日にエンドウがらを，各供試 薬剤に 5 分間浸漬, 風乾後, 早生温州15年生樹に被覆し て，9月10日に果実の発病状況を調疽した。結果は第 1 表のとおりであるが，そばかす病防除に使用しているボ

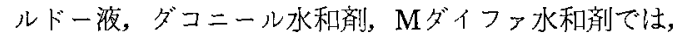
エンドウがら処理による発病阻止效果は認めなかった。 しかし，ワイダック乳剤処理区では，全く発病がみられ ず，顕著な発病阻止効果を示した。

第 1 表 薬戍処理飞上る防除効果

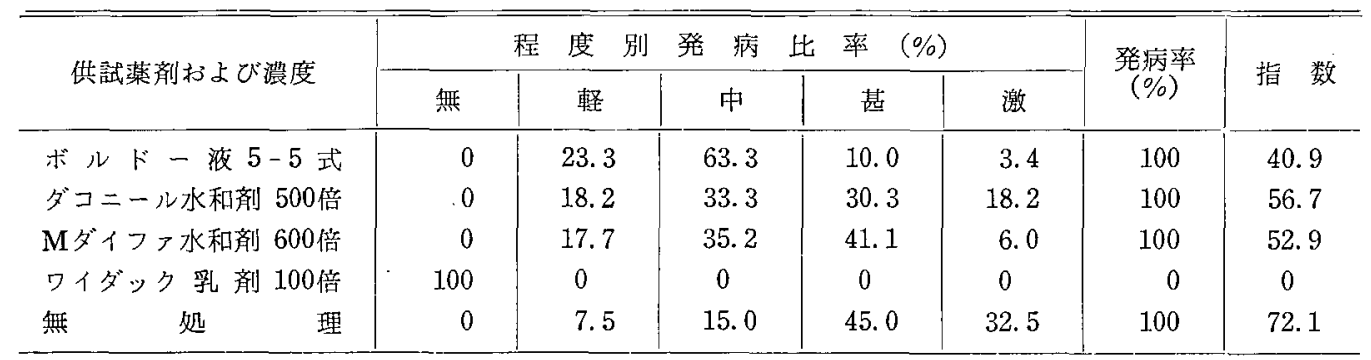

\section{II. 培 養 試 験}

実験 2 寒天培養液に供武薬剤を混和し，そばかす病 菌を平面培地の中央に静置して，培地上にお引る菌糸伸 長状海を測定したが，培陵 3 日後からダコニール水和剤, ジマンダイセン水和剤では，菌の伸長がみられ，14日以 降になると、ほとんど無処理と大差ない発育を示した。 しかし，ワイダック乳剂区では，調查期間中全く菌の伸 長は認めなかった。

実験 3 所定の薬䬉にそばかす病菌を 5 分間浸濽し，
あらかじめ用意した平面培地の中央に移して，菌系の伸 長状沉を測定した。ダコニール水和剤, ジマンダイセン 水和剮では 3 日後から菌の伸長がみられ，ワイダック乳 剤では5日後から緩慢であったが，菌の伸長が認められ た。

笑験 4 ワイダック乳剤は NAC $5 \%$ とCPA 25\% の混合剤でおのおのの成分について类験 2 に準じて病 菌の伸長抑制効果を检部した。結果は第 2 表のとおりで， DCPA 剂の効果が顕著でそばかす病菌に効果があるも のと思われる。

第 2 表そばかす病菌の伸長状況（mm）

\begin{tabular}{|c|c|c|c|c|c|c|c|c|}
\hline \multirow{2}{*}{ 供䧕桼 郕 } & \multirow{2}{*}{$\begin{array}{ll}\text { 稀 } & \text { 䣋 } \\
\text { 嶩 } & \text { 度 }\end{array}$} & \multicolumn{3}{|c|}{ 培 } & 養 & 日 & \multicolumn{2}{|l|}{ 数 } \\
\hline & & 2 日 & 日 & 日 & 10 日 & 15 日 & 17 日 & 19 日 \\
\hline ワイダック乳刻 & 100 倍 & $0 \times 0$ & $0 \times 0$ & $0 \times 0$ & $2 \times 1$ & $3 \times 1.6$ & $3 \times 2$ & $3 \times 2$ \\
\hline デナポン 乳㓮 & 500 倍 & $7.6 \times 6$ & $11.3 \times 8.6$ & $16.6 \times 14$ & $17.6 \times 16$ & $18.6 \times 16.3$ & $18.6 \times 16.3$ & $19.6 \times 17.3$ \\
\hline DCPA 乳 刘 & 100倍 & $0 \times 0$ & $0 \times 0$ & $2 \times 1.3$ & $2.6 \times 2.6$ & $4 \times 4.3$ & $5.3 \times 5: 3$ & $6 \times 5.6$ \\
\hline 処 & - & $11 \times 5.6$ & $13.6 \times 9.6$ & $18 \times 14.6$ & $18.6 \times 15.3$ & $19 \times 16.3$ & $19 \times 16.6$ & $20 \times 17.0$ \\
\hline
\end{tabular}




\section{III. 実用 試 験}

実験 5 ワイダック乳剂の湍度を原液，10，20，50， 100 倍とし，炤和47年 5 月16日にエンドウがら $1 \mathrm{~kg}$ 当り， $10,50,100,500,1,000,3,000 \mathrm{ml}$ あて澧厚少量散㸝し た。散布後早生温州の樹冠に被琵して，7月14日に果来 50個について癹病状況を調查した。その結果，散布量が
多くなるほど防除效果が高く，原液の濃擪微量散布・(10 $\mathrm{m} l)$ では，ほとんど防除效果を認めなかった。散布量と 濃度との組合せを検討すると，エンドウがら $1 \mathrm{~kg}$ 当り 50 $\mathrm{m} l, 100 \mathrm{~m} l$ 散布では，10倍から100倍までいずれも效果が みられず， $500 \mathrm{~m} l, 1,000 \mathrm{~m} l$ 散布で10倍液においてのみ， $3,000 \mathrm{~m} l$ 教布では 10 倍，20倍液で防除效果がみられ，笑 用性があると思われる。

第 3 表エンドウ文らへの散布效果

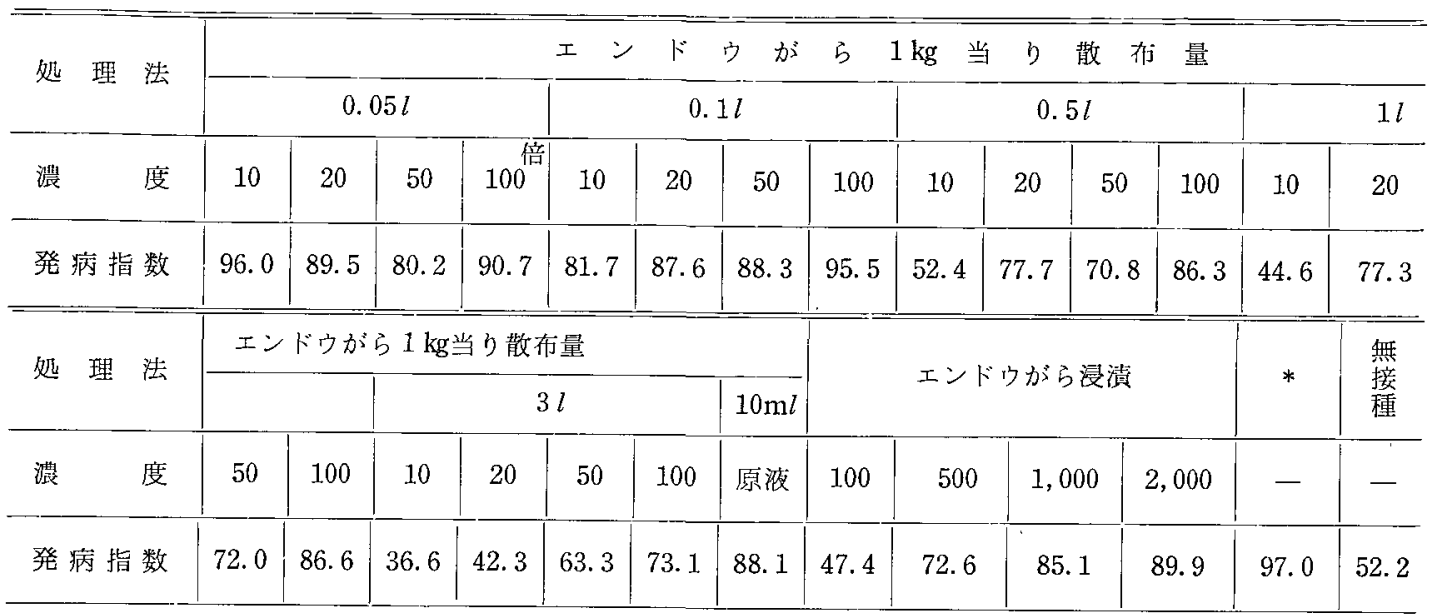

* 無散布のエンドウがらを接種

実験 6 エンドウがらをワイダック乳剂に浸漬する場 合の適正涶度を知るため，昭和 47 年 5 月16日に実験 1 に 準じて試験を行なった。その結果，100 倍液で最も効果 が高く，500倍でやや少り，1,000 倍，2,000倍では，ほ とんど防除効果を認めなかった。

契験 7 ミカン樹に対するワイダック乳剤の王木散布
試験を行なった。散布は，昭和47年4月25日，5月20日， 6 月 15 日の 3 回動噴で 1 樹当り $8 l$ を樹冠に十分散布し

て，7月26日に果実の発病状況を調查した。対照薬剂に シマンダィセン 600 倍を散布したが，ワイダック乳剤の $500,1,000,1,500,2,000,3,000$ 倍液は，いずれも対 照楽郕に比べ効果は劣った。

第 4 表 ワイダック乳剤の立木散布效喿

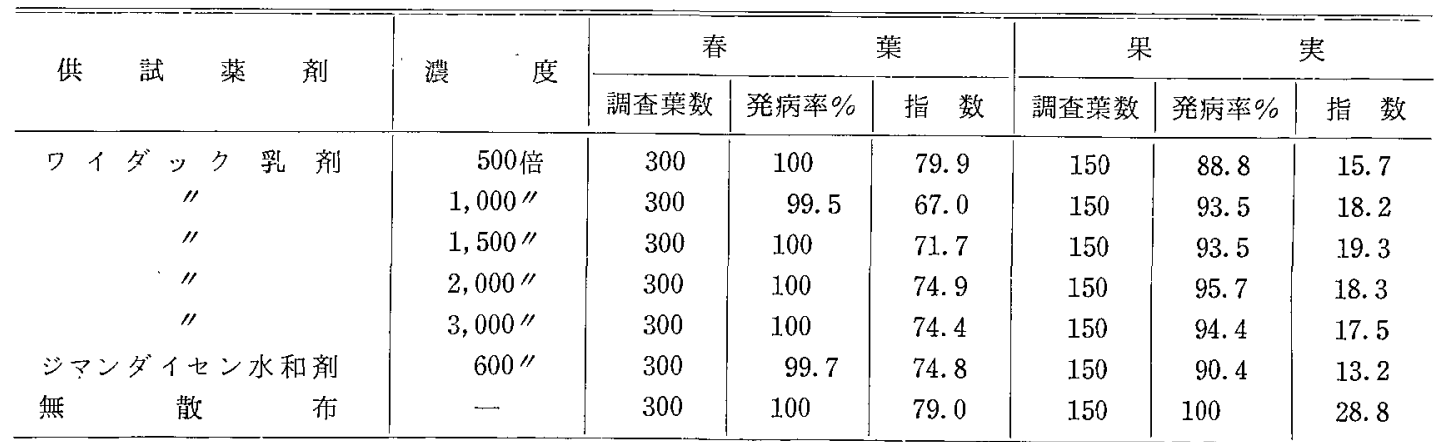

\section{IV. 総 合 考 察}

ミカン園で，除草羭として使用しているワイダック乳 剤の，そばかす病に対する防除効果ならびにこの使用法 について検諃した。そばかす病の伝染源であるエンドウ の褐紋病による杜死蕉葉をりイダック乳剂 100 倍刘に浸
漬すると，伝染源としての機能がなくなり，処理したエン ドウがらは，ミカン園内の有機物として利用することが 可能である。浸清液は，500倍でも有效であるが，1, 000 佔，2，000 倍になると效果は劣り，実用性はないものと 思われれる。また，エンドウの枯死蕉葉に散布する場合 は,ワイダック乳剤10倍液でエンドウ枯死茎葉 $1 \mathrm{~kg}$ 当り 
$500 \mathrm{~m} l$ 以上，20倍液で3,000 $\mathrm{m} l$ 以上散布する必要があり， 原液の微量散布，50倍，100倍液の3,000 $\mathrm{m} l$ 散布では，ほ とんど効果はみられない。ワイダック乳剤のミカン樹に 対する立木散布は，500倍から3，000倍について検脚した が，いずれも効果は劣り，なお，500倍液では若干の祭
葉があったことから，古木散有の丰用性はないものと思 われる。

\section{引用 文 献}

1) 山本滋·磯田隆晴 (1971) 九病虫研会吪 17: 3 4 2) 山本省二・山本 滋(1972) 植物防废 26: 263〜270.

\section{カンキッそうか病に対する massive dosage の散布時湖と防除効果について}

\section{甲 斐 一 平 (大分影津久見楒橘試験場)}

そうか病に対する薬凨防除の省力化については，ダイ ホルタン戍，ジチアノン剤などの有効な薬骫が開発され

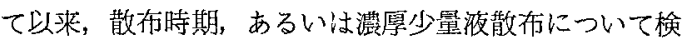
討され，散布回数の低減，散布時閂の短縮などで成果を あげている。さらに近年散布回数の低減の一方法として massive dosage について検傠されており，閉花期から 落花直後の散布で果実の発病を抑えた報告もある。しか し，大分県にお汀る春葉の発病最盛期はほほほ開花期と一 致しており, 潜伏期間を考慮すれば，開花期から落花直 後の散布では春葉の発病が増加することが䉥念されるの で, 3 カ年にわたって散布時期について検傠し，一灾の 結果がえられたので報皆する。

\section{試験 方 法}

試験は1970年〜1972年の3 为年行ない，薬剂は各年次 ともダイホルタン水和剤を供試した。供試樹, 樹令, 試 験の規模, 使用濃度および散布月日は第 1 表〜第 4 表の とおりである。ダィホルクン水和㓮は 1,000 倍を慣行使
用濃度とし， massive dosage は500 倍，300 倍とし， 1,000 倍同様に薬液が 葉からしたたり落ちる程度十分散 布した。したがって massive dosage の散布 1 回当り 投下薬量以慣行使用湎度の 2 〜. 3倍となる。

調查方法は春葉および果実について 1 樹当り 100 葉, 100 果（満たないものは全果）を抽出し，発生予察調查 要綱に準じて発病程度別に調香し，発病率，発病度を算 出した。

\section{試験 結 果}

\section{1970年度試験結果}

第 1 表のように無処理区に比べ散布区はいずれも春葉, 果実とも防除効果が認められる。散布時期については奻 芽期散布区の発病が春葉，果実とも最も少なく，以下散 布期が遅れるほど防除効果が低下しており春亲の発病と 果実の発病の間に $\gamma=0.959$ という高い相関が認められ た。

第 1 表 massive dosage $の$ 防除効果 (1970)

\begin{tabular}{|c|c|c|c|c|c|c|c|c|c|c|c|c|}
\hline \multirow[b]{2}{*}{ 薬 } & \multirow[b]{2}{*}{ 剤 } & \multirow[b]{2}{*}{ 名 } & \multirow{2}{*}{$\begin{array}{c}\text { 散 } \\
\text { (纤莱期) } \\
4.20\end{array}$} & \multirow{2}{*}{$\begin{array}{c}\text { 布 } \\
\text { (開花前) } \\
5.7\end{array}$} & \multirow{2}{*}{ 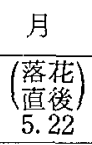 } & \multirow{2}{*}{ 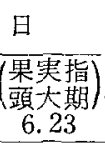 } & \multicolumn{2}{|c|}{ 越冬病斑 } & \multicolumn{2}{|l|}{ 春 } & \multicolumn{2}{|l|}{ 果 } \\
\hline & & & & & & & $\begin{array}{c}\text { 発病率 } \\
(\%)\end{array}$ & 発病度 & $\begin{array}{c}\text { 発病率 } \\
(\%)\end{array}$ & 発病度 & $\begin{array}{c}\text { 発病率 } \\
(\%)\end{array}$ & 発病度 \\
\hline \multirow[t]{4}{*}{ ダ } & 木ル & ン & $500 \times$ & & & & 0.7 & 0.1 & 1.7 & 0.3 & 9.7 & 2.1 \\
\hline & " & & & $500 x$ & & & 3.0 & 0.5 & 3.7 & 0.7 & 9.7 & 3.8 \\
\hline & " & & & & $500 \times$ & & 1.3 & 0.2 & 5.0 & 1.9 & 9.7 & 3.8 \\
\hline & "I & & & & & $500 x$ & 0.3 & 0.1 & 7.0 & 3.2 & 16.0 & 8.8 \\
\hline 無 & 述 & 理 & & & & & 1.3 & 0.4 & 9.0 & 4.3 & 28.1 & 15.4 \\
\hline
\end{tabular}

注）普通温州 12 年生 1 区 1 樹 3 反復

\section{1971年度試験結果}

試験 1 第 2 表のように春葉は発病が少なく，散布区 の間に有意な差が認められなかった。しかし，果実では 落果直後散布区の発病が最も低く，1,000 倍 3 回散布区 とほぼ同等かやや優る效果を示し，散布期が早いほど果 実の発病が多くなっているが，これは春葉の発病が少な
いことが影響したと慁われる。

試験 2 笨 3 表の上うに試験 1 と同様の結果が得ら れ，落花直後散布区の果実の発病が約芽期散布区より少 なく，1,000 倍 3 回散布区とほぼ同等の効果を示してお り, 春葉の発病が少ない場合注落花直後の散布が洧効と 思われる。 